\title{
Univentricular heart
}

INSERM

\section{Source}

INSERM. (1999). Orphanet: an online rare disease and orphan drug data base.

Univentricular heart. ORPHA:1464

Univentricular heart (UVH) is a severe congenital cardiac malformation characterized by both atria related entirely or almost entirely to one functionally single ventricular chamber. The clinical manifestations include cong estive heart failure, failure to thrive, cyanosis, hypoxemia and neurodevelopmental disabilities. 